\title{
How Student Worksheets Based Metacognitive can Improve Learning Outcomes on Material Price Index and Inflation?
}

\author{
R Jannah ${ }^{1}$, J Surjanti ${ }^{2}$, \& R Y Kurniawan ${ }^{3}$ \\ ${ }^{123}$ Economic Education, Universitas Negeri Surabaya, Indonesia \\ Email: roiyhatuljannah@gmail.com
}

\begin{abstract}
The purpose of this paper is to improve student learning outcomes. This study is a Research and Development (R\&D) using the 4D model Thiagarajan which includes stages Define, Design, Develop, and Disseminate but the Disseminate stage is not carried out. The findings showed that the feasibility of the material, language, evaluation, and graphics of $87 \%, 85 \%, 85 \%, 87 \%$ with a very decent category. The average $\mathrm{N}$-gain score got a score of 0.6 categorized as moderate and classical completeness of student learning outcomes is $90 \%$. While the results of the responses of students get an average percentage of $90,4 \%$ categorized as very feasible. Improved learning outcomes can be obtained using MMPII worksheets which include metacognitive features namely planning, monitoring, and evaluating. This study uses limited trials that were conducted on 20 students of XI IPS class Kanjeng Sepuh Senior High School.
\end{abstract}

Keywords: Worksheets; metacognitive; learning outcomes.

\section{INTRODUCTION}

The era of globalization is one of the signs of the $21^{\text {st }}$ century which be able to create changes in various aspects of life from the previous era. The $21^{\text {st }}$ century increases competitiveness between nations in the world so that it requires quality human resources. However, the challenge that now facing in Indonesia is the lack of quality human resources. The low level of human resources can be seen in the 2018 Program for International Student Assessment (PISA) data Indonesia is ranked 72 out of 77 countries in the fields of mathematics, reflection, conceptualization, generalization, skills, understanding, and high-level reasoning in these PISA activities (PISA, 2018). Thus, now Indonesia is currently preparing quality human resources with improving the quality of the National Education System.

The national education system aims to create an atmosphere of learning and learning process so that students actively develop their potential to have religious-spiritual strength, self-control, personality, intelligence, noble character, and the skills needed themselves, society, nation, and state (Depdiknas, 2003). The government is creating a curriculum to support the achievement of educational goals appoint formal educational institutions, namely kindergarten, elementary, junior high, and high school.

Based on the curriculum, economics is one of the subject fields for students majoring in social studies where many concepts focus on constructing student's knowledge. According to the constructivist theory, students build themselves knowing when they try to understand their experiences Shah (2019). One of the factors that can construct a student's comprehension is using metacognitive strategies. The importance of metacognitive learning is supported by Permendikbud (2016) concerning Process Standards in which it says 
that in learning activities, teachers provide opportunities for students to think, design, analyze, solve problems, find out how and why things are carried out, monitored, and evaluated. The activities of designing, monitoring, and evaluating are a series of activities from the metacognitive strategies.

According to Nasution \& Sinaga (2017), The main control of thinking activity is awareness. Awareness of thinking is relevant to metacognitive terms. Metacognitive learning strategies are needed to manage knowledge systematically. Metacognitive which was introduced by Flavell (1976) defines metacognitive as a person's ability to know and understand the process and how to learn on their own. Livingston (2004) states that metacognitive refers to higher-order thinking that involves active control over the cognitive processes involved in learning. Whereas Ormord (2011) define metacognitive simply as "thinking about thinking". According to Pulmones (2008) metacognitive is defined as the process of students planning, monitoring, and evaluating their learning process. Metacognitive activities are shown in table 1.

Table 1 Metacognitive Activity

\begin{tabular}{cl}
\hline $\begin{array}{c}\text { Dimensions of } \\
\text { Metacognitive }\end{array}$ & \multicolumn{1}{c}{ Manifestations of Dimensions } \\
\hline Planning Skills & - Thinking and writing what does known and does not know \\
& - Writing the learning goals \\
Monitoring Skills & - Identifying where to get information \\
& - Make important notes, diagrams, tables, etc. \\
Evaluating Skills & - Consulting the references \\
& - Reflecting the written objectives or make a list of all is achieved \\
& - Work thewarding oneself after learning and completing assignments \\
\hline
\end{tabular}

(Pulmones, 2008)

Metacognitive by Joyce and Calhoun (Yamin, 2013) is closely related to constructivism in building student knowledge. Metacognitive strategies can build student understanding of learning and understanding the context being studied. This strategy directs students to think about process models. Therefore, according to Nasution \& Sinaga (2017) the advantage of a metacognitive strategy is that it can help students to solve problems effectively, the teacher guides positive thinking, directs students' cognitive abilities, controls the thinking processes that are taking place. Besides, weaknesses are difficulty in managing the right time, difficulty in carrying out activities according to learning styles, and difficulty in creating discussion groups.

According to Hostetler, Luo, \& Stefaniak (2018), metacognitive can be an effective measurement in the right conditions with the experience of students in the learning process. Ellis, Denton, \& Bond (2014) states that effective learning is using metacognitive strategies. Research Händel, Artelt, \& Weinert (2013) show that a person's ability to regulate his learning process is very important in successful learning and work.

Based on the results of pre-research Kanjeng Sepuh Senior High School Sidayu Gresik, students have difficulty understanding economic subjects, because there are $73 \%$ of students consider many concepts, $80 \%$ with a lot of reasons to count them, $15 \%$ memorize it, and others as much as $5 \%$. Besides, $60 \%$ of students do not specify their learning objectives when they start learning so that the student's metacognitive skills are poorly trained. Besides, teaching materials used in schools are textbooks and worksheets. The textbooks used 
are appropriate because of the 2013 curriculumbased textbooks, whereas worksheets are used from publishers, not worksheets that are developed by teachers. The teacher worksheet developed by the teacher can facilitate students in understanding the material provided.

According to Nasution \& Sinaga (2017), there are some reasons why teachers need to develop student worksheets, namely: the availability of materials following curriculum demands, target characteristics. According to Majid (2011) and Hamdani (2011), there are categories of teaching materials based on the technology used, teaching materials are grouped into several categories: printed materials: handouts, books, modules, and student worksheets, and others. Audio teaching materials, cassettes, radio, and $\mathrm{CD}$ audio. Audiovisual teaching material: video compact disk and film. Visual teaching material: photos and pictures. Interactive multimedia teaching materials: Computer Assisted Instruction (CAI), compact disk (CD), and web-based learning materials. The existence of student worksheets aims to minimize the role of the teacher, but the role of students is active in the class and becomes an opportunity to demonstrate the ability and development of students' thinking processes (Susantini, Isnawati, \& Lisdiana, 2016). Student worksheets will be developed following metacognitive features.

Based on Permendikbud (2018) material price index and inflation contained in basic competencies 3.4 Analyzing price index and inflation. The characteristics of the price index and inflation material are students are required to be able to understand many concepts such as memorization, case studies, calculations, and the steps involved. Based on the learning outcomes of students indicate that the material is less than a minimum Drach criterion is that most of the material price index and inflation getting value 65 . Therefore a student worksheet is needed following the analysis of the students' needs. Kaymakci (2012) states worksheets are one of the most important teaching materials for achieving learning objectives. MMPII
(Metacognitive on Material Price Index and Inflation) worksheets are expected to be able to stimulate students to develop concepts and construct their knowledge. According to Nasution \& Sinaga (2017), his research revealed that the Student Worksheet Sheets with metacognitive strategies. Student worksheets are used in geometry methods. The metacognitive aspect is used to improve the ability to think creatively with the features used are planning, monitoring, and evaluating.

According to the description above, this study aims to describe the development, the feasibility of MMPII worksheets, the student response, as well as the improvement of student learning outcomes after the implementation of MMPII worksheets in XI IPS class of Kanjeng Sepuh Senior High School can provide positive benefits to all parties.

\section{METHOD}

This study is a research and development study using the 4D model Thiagarajan which includes the stages of defining, designing, developing, and disseminating. This developmental research will produce a product in the form of MMPII worksheets. This study uses a Pre-Experimental Design in the form of the One-Group Pre-test Post-test. The research procedures carried out starting from the defining stage, the design stage, then proceed to the stage of development, and dissemination.

The following is a brief description of this research procedure: the defining stage consists of curriculum analysis, students, assignments, concepts, and formulation of learning objectives. The design phase includes the stage of compiling the test, media selection, and format. The product development stage is carried out making students worksheets, including covers made in Excel while the contents are developed in Microsoft Word, then conducted a review, revision, and product validation by experts, and trials. The disseminated stage was not conducted by the researcher due to time and cost constraints. 
This research was conducted in March 2020 at Kanjeng Sepuh Senior High School. The learning process used as the object of research is learning in the price index and inflation. The subjects of the MMPII worksheets trial were carried out for XI IPS class Kanjeng Sepuh Senior High School Sidayu Gresik students as many as 20 students.

The instruments of data collection carried out at MMPII worksheets were (1) questionnaire study and validation of four experts (2) responses from students, (3) pre-test and post-test sheets. Techniques in analyzing data in the study obtained were the first study sheets of all experts using qualitative descriptive techniques and validation sheets of all experts applying the Likert scale. Student response data will be presented based on each component by applying the Guttman scale. While the analysis of student learning outcomes before and after using MMPII worksheets using the formula and the category of the normality gain score.

\section{RESULT AND DISCUSSION}

4D (Define, Design, Development, and Disseminate)

The results using 4D Thiagarajan as a research model consist of three phases, namely the definition phase includes analyzing curriculum known that Kanjeng Sepuh Senior High School is using the curriculum of 2013. Surjanti, Nugrohoseno, Budiono, \& Musfidah (2018) state that the importance of an interestbased curriculum is designed to achieve learning objectives. The range of age learners who become research trials around 16-17 years with thoughts level, knowledge, and different experience. Participants' learners assume that economic subjects are difficult to learn the material price index and inflation with many reasons to count, memorize it. Besides, students are not determining learning goals when they started learning that the metacognitive skills of students are poorly trained. And teaching materials used are still using student worksheets from publishers. Learners tend to like teaching materials that have color elements and images that match the material. Students and economics teachers want student worksheets that contain the process of working on the questions from the planning process to what will be done, monitoring work, and can evaluate the work done by themselves not just copying from the material which is already in the student worksheet. Concept analysis aims to produce a subject matter that is compiled systematically based on the Basic Competencies used, and then elaborated in the form of a concept map for the price index and inflation. After analysis of the concept, the next step is an analysis task to draw up a series of instructions to do the learners in the learning process with the activity of metacognitive planning, monitoring, and evaluating. Then the goal specifications are adjusted to the analysis of concepts and tasks based on Basic Competencies and material indicators.

The second stage of design is the stage for designing MMPII worksheets that are developed following the defining stage. The steps taken are the compilation of tasks that consist of phenomena and problems understanding that must be done by students with referring to the metacognitive features, namely planning, including Thinking and writing what is known and not known, Writing the learning goals, and Identifying where to get information. Monitoring includes Make important notes, diagrams, tables, etc, and Consulting the references. Evaluating includes Checking the written objectives or making a list of all that is achieved, Reflecting on the study strategies identifying what works and does not work, and Rewarding oneself after learning and completing assignments, thereby encouraging improved learning outcomes. Second, media selection, the media used in the development of MMPII worksheets in the form of phenomena presented with problems that must be solved by students accompanied with pictures, tables, and curves so that students are helped in 
understanding the material on price index and inflation. Third, the formulation of the format consists of determining the type of worksheets, title, material preparation, and initial MMPII worksheets design. The size of the MMPII worksheets is using A4 paper $(21 \mathrm{~cm} \times 29.7 \mathrm{~cm})$.

In the third stage, the MMPII worksheet development stage this development begins by translating the objectives and learning materials in an MMPII worksheet. To facilitate the development of MMPII worksheets, Microsoft Word was chosen to make the contents of worksheets and Excel to make the cover. Followed by entering learning material following the predetermined material concepts into the worksheets template. Examples of MMPII worksheets are presented in Figure 1. In each material is also provided with practice questions to measure students' understanding. Experts conduct studies and validations.

MMPII worksheets are advised to make improvements first. The basis used in the improvement process is an assessment in the form of input and suggestions from all experts after it has been revised and the feasibility of the product can be seen through the expert validation stage. Then MMPII worksheets can be tested on students. Before learning takes place the pretest questions will first be distributed to students then when learning takes place the use of worksheets will be applied. After that, a posttest will be given. And the last stage is the disseminate stage is not done by researchers because of limited time and money.

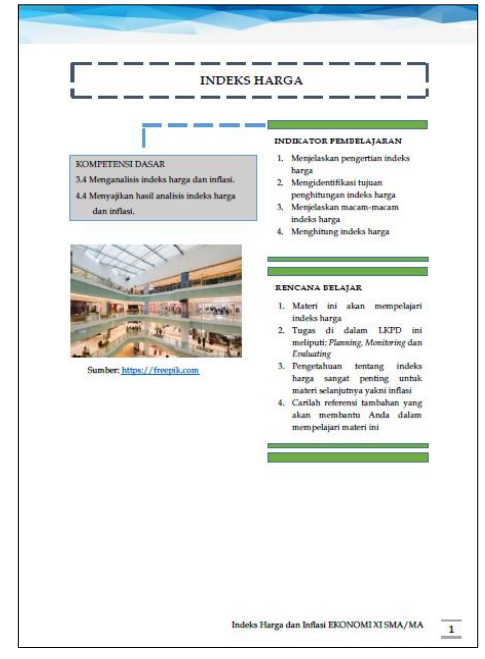

Figure 1: MMPII worksheets

\section{MMPII worksheets Feasibility}

The feasibility of MMPII worksheets was validated by experts, consisting of 4 lecturers and 1 economics teacher. Validator assessment includes 4 components namely material, language, evaluation, and graphics. The assessment data from the validator is qualitative and quantitative data. Qualitative data in the form of suggestions from the validator to improve MMPII worksheets. Quantitative data is a score assessment data from a validator at MMPII worksheets. Reviewers Suggestion for MMPII worksheets shows in Table 2, while the assessment of data from the validator is shown in Table 3. And based on table 3, the Figure 1 diagram shows the average score of the validation results.

Table 1: Reviewers Suggestion for MMPII Worksheets

\begin{tabular}{|c|c|c|}
\hline No & Reviewers & Suggestion \\
\hline \multirow[t]{2}{*}{1} & Material expert & Each sub-chapter must have a phenomenon \\
\hline & & There are grading instructions and answer keys on the back page \\
\hline \multirow[t]{2}{*}{2} & Linguist & Check all the typos and foreign languages \\
\hline & & Use standard Indonesian \\
\hline 3 & Evaluation expert & Some terms need to be checked again \\
\hline 4 & Graphic expert & Pay attention to the source of the image and composition \\
\hline
\end{tabular}


Table 2: Assessment Data from Validator

\begin{tabular}{llc}
\hline No. & Component & Percentage \\
\hline 1 & Material & 87 \\
2 & Language & 85 \\
3 & Evaluation & 85 \\
4 & Graphic & 87 \\
\hline Average Percentage & $\mathbf{8 6}$
\end{tabular}

Based on table 3 validator assessment data that the average score obtained from four experts at $86 \%$ shows that MMPII worksheets obtained the category "Very Eligible". This is supported by Lestari \& Hidayah (2014) show that student worksheets eligibility gained a strong category with an average validation score of $85.33 \%$. Thus, it can be concluded that MMPII worksheets are suitable for use in the learning process.

\section{Learning Outcomes}

Learners' outcomes can be known by the students that given a pre-test and post-test before and after using MMPII worksheets. Students are given a pre-test before the learning process uses MMPII worksheets to find out their initial knowledge. After the learning process using MMPII worksheets, learners are given the post-test. The average result of learning before use MMPII worksheets is 62 , the average of learning outcomes (post-test) for learners after using MMPII worksheets at 85,75 . In the classical completeness, the pretest of students is $25 \%$, whereas in the classical completeness post-test has been reached about $90 \%$.

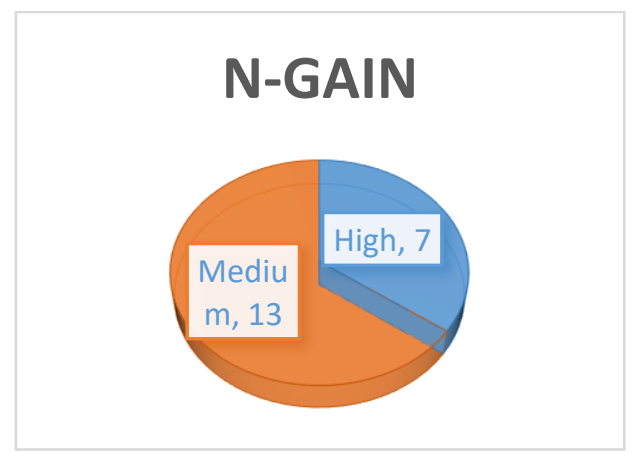

Figure 1: Improved Learning Outcomes
Based on Figure 2 can be obtained that the students of the XI IPS class clicking natural learning outcome. The result of learning can be able to increase if it gets a Gain Score > 0.3. Learning outcomes for XI IPS students Kanjeng Sepuh Senior High School no one got an N-gain $<0.3$. Participants did obtain N-Gain > 0.3 categorized as being that as many as 13 learners, while learners who experience learning outcome $>0.7$ categorized as high as 7 learners. The average $\mathrm{N}$-gain score gets 0.6 and is categorized as a medium. Students are categorized as high and moderate due to an increase in the score of the results of the pretest to post-test. So it indicates that learning using MMPII worksheets can improve learning outcomes. This is in line with research Hostetler, Luo, \& Stefaniak (2018) explaining that metacognition as a tool to encourage improvement in student learning outcomes.

\section{Student Responses}

Student Responses is a response given after students get a stimulus. MMPII worksheets development trials were conducted with limited trials on 20 students of XI IPS class Kanjeng Sepuh Senior High School. In the implementation, students are given sheets of student responses to the development of MMPII worksheets. The student response sheet consists of several aspects namely the feasibility of the content, the feasibility of presentation, the feasibility of language, and the feasibility of graphics.

Table 3: Students Responses

\begin{tabular}{|c|c|c|c|c|}
\hline Aspect & Yes & No & $\%$ & Category \\
\hline 1 & 19 & 1 & 95 & $\begin{array}{l}\text { Very } \\
\text { Decent }\end{array}$ \\
\hline 2 & 4 & 16 & 80 & $\begin{array}{l}\text { Very } \\
\text { Decent }\end{array}$ \\
\hline 3 & 20 & 0 & 100 & $\begin{array}{l}\text { Very } \\
\text { Decent }\end{array}$ \\
\hline 4 & 18 & 2 & 90 & $\begin{array}{l}\text { Very } \\
\text { Decent }\end{array}$ \\
\hline 5 & 19 & 1 & 95 & $\begin{array}{l}\text { Very } \\
\text { Decent }\end{array}$ \\
\hline
\end{tabular}




\begin{tabular}{|c|c|c|c|c|}
\hline Aspect & Yes & No & $\%$ & Category \\
\hline 6 & 16 & 4 & 80 & $\begin{array}{c}\text { Very } \\
\text { Decent }\end{array}$ \\
\hline 7 & 20 & 0 & 100 & $\begin{array}{l}\text { Very } \\
\text { Decent }\end{array}$ \\
\hline 8 & 5 & 15 & 75 & Worthy \\
\hline 9 & 19 & 1 & 95 & $\begin{array}{l}\text { Very } \\
\text { Decent }\end{array}$ \\
\hline 10 & 19 & 1 & 95 & $\begin{array}{l}\text { Very } \\
\text { Decent }\end{array}$ \\
\hline 11 & 18 & 2 & 90 & $\begin{array}{l}\text { Very } \\
\text { Decent }\end{array}$ \\
\hline Total & 177 & 43 & 995 & $\begin{array}{l}\text { Very } \\
\text { Decent }\end{array}$ \\
\hline Average & & & 90,4 & $\begin{array}{l}\text { Very } \\
\text { Decent }\end{array}$ \\
\hline
\end{tabular}

Students are provided a questionnaire containing questions and answers, with answers "Yes" and "No" where the answer "Yes" gets a score of 1 while the answer "No" gets a score of 0 . Students' responses in XI IPS class Kanjeng Sepuh Senior High School get results "yes" answers are 177 and "no" answers 43 out of 220 answers with 11 question items. The results of the students' response data are analyzed with quantitative descriptive form data numbers and analyzed using sentences. Based on Table 4, it can be seen that the field trials have obtained an overall aspect of $90.4 \%$. Then the field trials fall into the "very decent" category. Lestari \& Hidayah (2014) supported research that shows that the field test questionnaire obtained a positive response from students.

\section{CONCLUSION}

From the MMPII worksheets development research, it can be concluded: (1) Development uses several stages, namely Define, Design, Development, and limited trials. (2) Percentage feasible material, language, evaluation, and graphics are $87 \%$, $85 \%, 85 \%, 87 \%$ categorized as very feasible and the average percentage of $86 \%$ seeing very feasible (3) average $\mathrm{N}$-gain score of students in for XI IPS class Kanjeng Sepuh Senior High School got a score of 0.6 is average and classical completeness learning outcomes of students at 90\% (4) The results of the responses of students get an average percentage of $90.4 \%$ categorized as very feasible. Improved learning outcomes can be obtained using MMPII worksheets which include metacognitive features namely planning, monitoring, and evaluating. It can be said that students' learning outcomes following N-Gain score calculations can encourage learning outcomes so that classical completeness can be achieved and MMPII worksheets are effective to use.

\section{ACKNOWLEDGMENT}

The biggest award was given to all the parties who assisted in this research, namely Kanjeng Sepuh Senior High School, such as students in XI IPS class, teachers, and school administration. As well as Universitas Negeri Surabaya who assists in conducting the study and institutions that support researchers to successfully conduct this research and report the results.

\section{REFERENCES}

Depdiknas. (2003). Undang-Undang Nomor 20 Tahun 2003, Tentang Sistem Pendidikan Nasional. (1), 6-8. https://doi.org/10.16309/j.cnki.issn.10071776.2003.03.004

Ellis, A. K., Denton, D. W., \& Bond, J. B. (2014). An Analysis of Research on Metacognitive Teaching Strategies. Procedia - Social and Behavioral Sciences, 116, 4015-4024. https://doi.org/10.1016/j.sbspro.2014.01. 883

Flavell, J. H. (1976). Metacognition and Cognitive Monitoring A New Area of Cognitive-Developmental Inquiry. American Psychologist, 34(10), 906-911. https://doi.org/10.1002/bit.23191

Hamdani. (2011). Teaching and Learning Strategies. Bandung: Pustaka Setia.

Händel, M., Artelt, C., \& Weinert, S. (2013). Assessing metacognitive knowledge: development and evaluation of a test instrument. Journal Für Bildungsforschung Online, 5(2), 162188. 
Hostetler, K., Luo, T., \& Stefaniak, J. E. (2018). Aligning information literacy assessment with metacognitive strategies. Journal of University Teaching and Learning Practice, 15(5).

Kaymakci, S. (2012). A Review of Studies on Worksheets in Turkey, US-China Education. 4, 57-64.

Lestari, F. D., \& Hidayah, R. (2014). Development Of Students Worksheet Based on Metacognitive Strategy on Stoichiometry Matter for X Grade Senior High School Students. Unesa Journal of Chemical Education, 3(1), 114-118. https://doi.org/10.14419/ijet.v7i4.30.220 03

Livingston, J. A. (2004). Metacognition: An Overview. International Journal of Science Education, 26(3), 365-383. https://doi.org/10.1080/09500690320001 19401

Majid, A. (2011). Lesson Planning: Developing Teacher Competency Standards. Bandung: Remaja Rosdakarya.

Nasution, T. K., \& Sinaga, B. (2017). Development of Student Worksheet Geometry Based Metacognitive Strategy Through Creative Thinking Ability Development of Student Worksheet Geometry Based. IOSR Journal of Research \& Method in Education (IOSRJRME), (September), 9-18. https://doi.org/10.9790/73880704041018

Ormord, J. (2011). Educational Psychology: Developing Leaner. Boston: Person Education.

Permendikbud. (2016). Peraturan menteri pendidikan dan kebudayaan No. 22 tahun 2016 tentang proses standar pendidikan dasar dan menengah. Peraturan Menteri Pendidikan Dan Kebudayaan. Retrieved from http://bsnp-indonesia.org/wpcontent/uploads/2009/06/Permendikbud_ Tahun2016_Nomor022_Lampiran.pdf

Permendikbud. (2018). Peraturan Menteri Pendidikan dan Kebudayaan Republik Indonesia Nomor 37 Tahun 2018, tentang Perubahan Atas Peraturan Menteri Pendidikan dan Kebudayaan Nomor 24 Tahun 2016, tentang Kompetensi Inti dan
Kompetensi Dasar. 1-534.

PISA. (2018). Program for International Student Assessment (PISA): 2015 Results - Mathematics Literacy: Average Scores.

Pulmones, R. (2008). Learning Chemistry in a Metacognitive Environment. The AsiaPacific Education Researcher, 16(2). https://doi.org/10.3860/taper.v16i2.258

Shah, K. R. (2019). Effective Constructivist Teaching Learning in the Classroom. Shanlax International Journal of Education, 7(4), 1-13. https://doi.org/10.34293/education.v7i4.6 00

Surjanti, J., Nugrohoseno, D., Budiono, \& Musfidah, H. (2018). The implementation of interest-based entrepreneurship curriculum in the Theory of Economics course. IOP Conference Series: Materials Science and Engineering, 296(1). https://doi.org/10.1088/1757899X/296/1/012012

Susantini, E., Isnawati, \& Lisdiana, L. (2016). Effectiveness of genetics student worksheet to improve creative thinking skills of teacher candidate students. Journal of Science Education, 17(2), 7479.

Yamin, M. (2013). Strategies and Methods in the Learning Model. Jakarta: Press Group. 